$\begin{array}{ll} & \text { Etnográfica } \\ \text { etnográfica } & \text { Revista do Centro em Rede de Investigação em }\end{array}$

Antropologia

vol. $12(1) \mid 2008$

Vol. $12(1)$

\title{
O trabalho da crioulização: as práticas de nomeação
} na Guiné colonial

The workings of Creolization: naming practices in colonial Guinea-Bissau

\section{Wilson Trajano Filho}

\section{(2) OpenEdition}

Journals

\section{Edição electrónica}

URL: https://journals.openedition.org/etnografica/1623

DOI: 10.4000/etnografica.1623

ISSN: 2182-2891

\section{Editora}

Centro em Rede de Investigação em Antropologia

\section{Edição impressa}

Data de publição: 1 maio 2008

Paginação: 95-128

ISSN: 0873-6561

\section{Refêrencia eletrónica}

Wilson Trajano Filho, «O trabalho da crioulização: as práticas de nomeação na Guiné colonial», Etnográfica [Online], vol. 12 (1) | 2008, posto online no dia 19 junho 2012, consultado o 11 fevereiro 2022. URL: http://journals.openedition.org/etnografica/1623; DOI: https://doi.org/10.4000/ etnografica. 1623

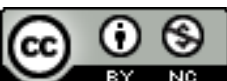

Etnográfica is licensed under a Creative Commons Attribution-NonCommercial 4.0 International License. 


\title{
O trabalho da crioulização: as práticas de nomeação na Guiné colonial
}

\author{
Wilson Trajano Filho
}

\begin{abstract}
Este trabalho analisa as práticas de nomeação nos aglomerados urbanos crioulizados da Guiné-Bissau no período colonial. Partindo de um corpus de 496 nomes colhidos nas listas de falecimentos publicadas pela Junta de Saúde do governo colonial entre 1892 e 1900, o trabalho descreve o processo de crioulização da sociedade colonial a partir da análise dos nomes das pessoas. Tendo como ponto de partida os padrões de nomeação em voga em Portugal e nas sociedades indígenas da Guiné colonial, a análise realizada mostra a dinâmica das práticas crioulas de nomeação, revelando sua instabilidade, criatividade e multidirecionalidade.
\end{abstract}

PALAVRAS-CHAVE: crioulização, práticas de nomeação, Guiné-Bissau.

A MATÉRIA-PRIMA DESSE TRABALHO SÃO OS NOMES PESSOAIS NA GUINÉ colonial. Porém, como se verá a seguir, a natureza descarnada dos dados de que disponho faz com que o exame das formas de nomeação não seja um fim em si mesmo, sendo, antes, um meio para observar e compreender a operação de uma dinâmica social que em larga medida explica a variabilidade encontrada nos dados brutos. Tenho chamado de crioulização à dinâmica social em que se misturam, chocam e interpenetram forças, processos, valores e símbolos oriundos de duas vertentes civilizatórias - a africana e a européia -, dando luz a uma entidade terceira, uma síntese societária que historicamente tem assumido e se percebe em formas tão diferentes como a de um aglomerado de casas patrimoniais (as gãs do século XVIII e da primeira metade do século XIX), uma elite orientada pela mística da exclusividade na segunda metade dos oitocentos, uma província englobada por uma totalidade imperial (a Guiné Portuguesa) e, no presente, um Estado-nação (Trajano Filho 1998; 2005a; 2005b). Sociedade crioula é a locução objetiva que tenho usado para me referir a essa unidade social que resulta da crioulização. 


\section{O CONTEXTO HISTÓRICO DOS DADOS}

As informações recolhidas sobre os nomes pessoais na Guiné se referem aos dois principais agregados urbanos dessa província no último quartel do século XIX, Bolama e Bissau. Este foi um tempo de inflexão na dinâmica da sociedade crioula nas povoações costeiras da Guiné (as praças). O declínio do ciclo econômico baseado no cultivo do amendoim nas feitorias do rio Grande de Buba (que substituiu gradativamente a economia do tráfico de escravos a partir de 1830) teve um decisivo impacto no desenvolvimento de Bolama no início da década de 1890, travando a sua crescente importância como o principal centro comercial da Guiné e fazendo com que esse papel voltasse a ser assumido por Bissau. Bolama havia crescido vigorosamente depois que o contencioso com os ingleses da Serra Leoa sobre sua posse foi resolvido em favor de Portugal em 1870. As feitorias que ali existiam desde os anos 1830, voltadas para o cultivo do amendoim, e sua proximidade com os outros centros de produção estabelecidos no rio Grande de Buba (o Forriá) foram determinantes para o desenvolvimento da cidade. Sendo o centro para onde se dirigia o amendoim antes de ser exportado para a Europa, Bolama atraiu as grandes casas exportadoras européias que operavam na costa africana, tornando-se assim a candidata natural para sediar o governo provincial quando a Guiné passou a ser uma província autônoma de Cabo Verde em 1879. A implantação do aparato de governo provincial na povoação implicou um processo de urbanização acelerada, com a construção de edifícios para abrigar os órgãos de governo, como a alfândega, o quartel, o hospital, a residência do governador, escolas e tantas outras repartições públicas. A febre das construções e a chegada dos novos funcionários coloniais vindos de Portugal, Cabo Verde, mas também recrutados das outras povoações crioulas da Guiné, tiveram o efeito de atrair um grande número de gente para trabalhar na edificação dos prédios públicos e das casas particulares (pedreiros, carpinteiros, serralheiros) e nos serviços voltados para atender as necessidades dos funcionários coloniais e dos prósperos comerciantes (carregadores, criados domésticos, costureiras, alfaiates, engomadeiras, remadores, lavadeiras, tecelões e empregados comerciais).

Porém, por volta de 1890 a curva de crescimento e desenvolvimento de Bolama mudou de inclinação, sinal de uma crise que desde longe vinha se fazendo sentir. Terminada a implantação do aparato administrativo colonial, a continuidade da dinâmica social passou a depender muito do vigor da exportação do amendoim, que, no entanto, começava a declinar. ${ }^{1}$ As razões para

1 As fontes sobre o comércio exportador do amendoim na Guiné são muito heterogêneas, não permitindo comparações numa série histórica mais longa. Para alguns anos, a produção é registrada em hectolitros; para outros, os dados são apresentados em termos dos valores exportados em francos franceses; para outros ainda, os valores são apresentados em milhares de réis. O leitor interessado poderá encontrar mais informações em Pélissier (1989, I: 165, 247; II: 63) e em Trajano Filho [continua] 
tão acentuado declínio incluem a queda acentuada dos preços no mercado internacional, a taxação excessiva, o sistema de produção existente nas feitorias e a crescente infertilidade do solo, causada por anos de queimadas dos terrenos. Importantes também para a compreensão desse declínio foram as guerras inter-étnicas entre mandingas, beafadas e fulas, que levaram muitos camponeses a deixar o seu chão nativo, causaram incertezas entre os proprietários e desviaram o importante comércio com o interior para os entrepostos franceses no sul, na região da atual Guiné-Conacri. ${ }^{2}$

As incertezas no Forriá e o fim das feitorias fizeram com que a economia colonial exportadora se voltasse para outros produtos, como o látex da borracha e a amêndoa da palmeira, cuja obtenção não passava pelo tipo de contrato estabelecido nas feitorias. Com essa mudança, Bissau voltou a ser o principal centro comercial da Guiné. Porém, a década de 1890 também foi um tempo de crise para a cidade, apesar da crescente efervescência comercial. A vida cotidiana da cidade permanecia cada vez mais dependente dos indígenas papéis, que eram os donos daquele chão, e dos grumetes (africanos mais ou menos cristianizados com estreitos laços com a população indígena). Era através desses dois grupos que a povoação obtinha os alimentos básicos para o consumo diário e recrutava a força de trabalho para operar o comércio (os remadores, carregadores, marinheiros, vendedores e compradores ambulantes, entre outros). Apesar de ser construída ao redor de uma fortaleza e de estar protegida desde 1844 por uma paliçada, a cidade era constantemente ameaçada pelos indígenas e grumetes.

As duas povoações tinham uma população muito heterogênea, o que é um ingrediente necessário para a operação da crioulização. E nenhum dos grupos que a constituíam detinha o necessário poder econômico e militar para exercer uma dominação plena e criar uma hegemonia. Tinham, portanto, que constituir alianças frágeis e temporárias uns com os outros e alcançar um compromisso dinâmico entre os diversos valores e práticas que coexistiam num equilíbrio instável e continuamente negociado.

Bissau e Bolama abrigavam umas boas dezenas de franceses e seus agentes franco-africanos, que dominavam o comércio exportador. Em competição com eles, e cada vez mais presentes encontravam-se os alemães e italianos, que eram gerentes e proprietários de casas comerciais de porte médio. Havia ainda um grupo de mestiços da Serra Leoa que representava os interesses ingleses. Além dos estrangeiros, era crescente a presença de portugueses metropolitanos, uns vindos no processo de implantação do aparato administrativo, outros para

(1998: 278). Com relação ao número das feitorias produtoras, de acordo com Vasconcelos (1917: 49), havia apenas três feitorias em atividade em 1889, das 115 que existiam em 1875.

2 Para as fontes da época, consultar Astrié (1885) e Brosselard (1889). Entre os historiadores coloniais, ver Carreira (1962) e Teixeira da Mota (1950). Na atualidade, Bowman (1987; 1997) tem realizado uma detalhada pesquisa documental sobre a matéria. 
tentar a sorte como comerciantes ou profissionais especializados. Crescente também foi a chegada dos cabo-verdianos, cujo fluxo para a Guiné se intensificou depois das secas intensas que assolaram o arquipélago na década de 1860. Foram atraídos primeiro para as pontas produtoras de amendoim. A seguir, outros vieram como funcionários nas posições intermediárias da administração colonial e como militares. Veio também do arquipélago todo um conjunto de gente que, já tendo parentes ou protetores na Guiné, buscavam fugir das duras condições das ilhas, trabalhando como caixeiros, empregados comerciais, prestadores de serviços ou tentando a sorte no interior produzindo aguardente, comprando e vendendo os produtos da terra. Um último grupo de estrangeiros a ser mencionado são os angolanos, que compunham a maioria da tropa regular na Guiné. Eram cerca de 400 soldados, metade deles aquartelados em Bolama.

Da gente nascida na terra, que compunha a maioria da população de Bissau e Bolama, vale destacar primeiro as proeminentes famílias crioulas que se percebiam como lusitanas e cristãs há várias gerações. Com fortes laços com a gente de Cabo Verde, elas eram verdadeiros grupos corporados que tomavam a forma de casas patrimoniais autônomas, as gãs, que controlavam a ponta final africana do comércio de escravos e assumiam muitas funções de governo. Com o fim do tráfico atlântico, perderam parte de seu poder, passando a se reproduzir nas atividades ligadas ao comércio local (nas cidades crioulas e em entrepostos no interior, que deixavam a cargo de parentes e aderentes) e nas posições médias do funcionalismo público.

O segundo grupo de gente da terra que circulava e residia nessas cidades era o dos grumetes. Trata-se de uma classe difusa, composta por indígenas de procedência étnica variada que se percebiam como cristãos, mas nem sempre eram assim percebidos pelos europeus. Como aderentes-dependentes das famílias crioulas proeminentes, sua principal atividade era auxiliá-las no comércio com as povoações indígenas onde tinham parentes como remadores, carregadores, pilotos e intermediários comerciais. Em Bissau, viviam do lado exterior da murada desde 1844, mas freqüentavam a vila fortificada diariamente. Em Bolama, viviam misturados com os outros grupos. No final do século XIX suas relações com as famílias crioulas, com os cabo-verdianos e com os europeus ficaram marcadas por uma forte interdependência, assim como eram os seus laços com as populações indígenas que viviam nos arredores dos aglomerados crioulos. Eram formalmente sujeitos às autoridades coloniais, mas eram governados por suas próprias regras e freqüentemente se rebelavam contra as ordens do governo, encontrando suporte nos seus parentes indígenas. ${ }^{3}$

3 Lopes de Lima (1844, I: 126) nos deixou algumas informações preciosas sobre esse grupo. Conferir ainda Trajano Filho (1998: 106-115). Uma breve passagem em Barros (1882:723) menciona as possibilidades de confusão entre esse grupo e os indígenas que viviam próximos às povoações crioulas. Isto ainda será tratado com maior pormenor mais adiante. 


\section{CORPUS DE NOMES: UMA BREVE EXPLICAÇÃO}

As informações que serão analisadas nesse trabalho são oriundas de uma série de listas de falecimentos publicadas pela Junta do Serviço de Saúde entre 1892 e 1900 no Boletim Oficial da Guiné Portuguesa. Porque são produzidas por uma instituição do Estado colonial para efeito de controle da vida social, tomo os nomes que nelas aparecem como nomes oficiais, reconhecidos como tal pelo Estado. Vale notar, no entanto, que até a publicação do Diploma Legislativo 51 de 23 de maio de 1922, que nomeava uma comissão para adaptar o Código de Registo Civil da metrópole às condições sociais e culturais da Guiné, as certidões de nascimento, casamento e óbito eram emitidas pelo registro paroquial, cabendo às autoridades municipais a emissão de bilhetes de residência e de identidade, bem como de passes e autorizações para circulação pelo território. E mesmo após a publicação do referido diploma o funcionamento de fato do registo civil em toda a colônia teve que esperar pelo conhecimento mais aprofundado do modo de vida das populações indígenas, em meados dos anos 50 (Carreira 1967: 43).

Os dados de que disponho dizem respeito a 303 indivíduos que faleceram nesse período em Bolama e Bissau. ${ }^{4}$ Nelas constam os nomes de 302 pessoas, com informações adicionais sobre suas idades, estado civil, local de nascimento e ocupação. ${ }^{5}$ Muito importantes para esse trabalho são os dados de filiação de 194 indivíduos falecidos, havendo, portanto, 109 pessoas com filiação ignorada. Os agentes coloniais que confeccionaram as listas sempre se mostraram rebeldes ao que mais tarde se tornou assentado na tradição antropológica - que a filiação é sempre bilateral. Seja por carecer de informações precisas e completas, seja por viés ideológico ou ainda por descuido, preguiça ou idiossincrasia, o fato é que a filiação registrada nas listas sempre foi unilinear, na maioria das vezes aparecendo o nome do pai (ver mais adiante). O quadro 1 sintetiza o tipo de dados disponíveis nas listas.

As informações sobre idade, estado civil e ocupação das pessoas falecidas encontram-se resumidas no quadro 2 .

O grupo ocupacional que mais aparece no rol dos falecidos são os militares, totalizando 69 indivíduos. No período examinado, a Guiné dispunha de uma força regular com cerca de 400 soldados, a maioria aquartelada em Bolama e Bissau. Portanto, os militares falecidos representavam cerca de 15 por cento do efetivo total. Os conflitos com as populações indígenas, resistentes à ocupação colonial, por certo contribuíram para esse percentual, mas tal causa não deve ser

4 Este não é o total de óbitos do período. Segundo o movimento obituário publicado como anexo do $\mathrm{n}^{\circ} 7$ do Boletim Oficial da Guiné de 1898, referente aos anos de 1886 a 1895, nota-se que somente entre 1892 e 1895 faleceram 453 pessoas.

5 Nessas listas somente uma pessoa do sexo feminino aparece sem nome. Morreu com 12 dias de vida e aparece na lista como "recém nascida". 
Quadro I

Quantitativos sobre nomeação e filiação

$\begin{array}{ll}\text { Indivíduos falecidos } & 303 \\ \text { Indivíduos falecidos nomeados } & 302 \\ \text { Indivíduos com filiação determinada } & 194 \\ \text { Indivíduos sem filiação determinada } & 109\end{array}$

Quadro 2

Idade, estado civil e ocupação

Indivíduos com idade definida

272

Indivíduos com estado civil definido

257

Indivíduos com ocupação definida
303

02

94

109

superestimada. Segundo Pélissier (1989 II: 266), morreram em combate 54 militares do efetivo regular entre 1891 e 1908, um período duas vezes maior do que o aqui examinado. Além disto, a maioria dessas mortes aconteceu nos rincões da Guiné, distantes das duas povoações crioulas. A maioria dos militares falecidos mencionados nas listas era nascida em Angola (43 mortos), seguidos pelos nascidos em Portugal (19 mortos). As precárias condições de salubridade dos quartéis de Bolama e Bissau, as más condições de alimentação da tropa, assim como as dificuldades de aclimatação dos portugueses e angolanos (especialmente no que se refere à resistência às cepas locais dos germes patogênicos) contribuíram mais para esses falecimentos do que os combates contra os indígenas no interior. O segundo maior grupo ocupacional é o dos trabalhadores, com 41 mortos. Não disponho de informações adicionais sobre esse grupo. Tudo leva a crer que se tratava de uma categoria difusa que englobava a força de trabalho não especializada, os ajudantes de toda ordem. A imensa maioria desse grupo era composta por gente nascida na Guiné. A seguir vem o grupo dos comerciantes (com 19 mortos), os empregados comerciais e caixeiros (17 mortos ao todo), as lavadeiras (com 12), os trabalhadores marítimos (com 9) e os grupos profissionais como as costureiras e alfaiates (6 mortos), pedreiros (5) e carpinteiros (3).

A relação entre solteiros e casados era esmagadoramente favorável aos primeiros, o que está em consonância com todas as descrições do país no período. Apenas 14 indivíduos da lista eram casados - cinco mulheres e nove homens. A maioria dos casados era nascida em Portugal (cinco pessoas), seguida por três cabo-verdianos e três guineenses. Quando se leva em conta a distribuição em termos do local de nascimento, como mostra o quadro 3, os dados sobre 
o estado civil adquirem outros contornos. Os casados nascidos em Portugal representavam cerca de 20 por cento do grupo com essa naturalidade (de 34 pessoas). Os casados cabo-verdianos eram 14 por cento dos ilhéus e as pessoas casadas nascidas na Guiné, pouco mais de 5 por cento dos guineenses.

\section{Quadro 3}

Local de nascimento

\begin{tabular}{lcccc}
\multicolumn{1}{c}{ Local de nascimento } & Homens & Mulheres & Sexo desconhecido & Total \\
Guiné & 76 & 78 & 8 & 162 \\
Cabo Verde & 28 & 15 & 0 & 43 \\
Portugal & 32 & 2 & 0 & 34 \\
Angola & 47 & 0 & 0 & 47 \\
África não portuguesa & 6 & 1 & 0 & 7 \\
Europa & 7 & 0 & 0 & 7 \\
Outras colônias portuguesas & 3 & 0 & 0 & 3 \\
Total & 199 & 96 & 8 & 303
\end{tabular}

As informações sobre o local de nascimento dos falecidos são condizentes com o quadro da população das duas povoações esboçado na seção anterior. Longe de serem povoações isoladas, habitadas por uma população homogênea, as listas de falecimento sugerem que elas eram habitadas por gente de proveniência muito variada. Da Europa, além de Portugal, havia franceses, alemães e italianos. Da África não portuguesa, gente do Senegal, da zona então conhecida como Rivières $d u$ Sud (atual Guiné Conacri) e da Serra Leoa. Isto pode ser percebido no próprio corpus dos nomes, que contém prenomes e sobrenomes portugueses, alemães, franceses, ingleses, italianos, das sociedades africanas islamizadas do interior, dos pequenos grupos da costa da Guiné, das sociedades falantes das línguas bantu de Angola, além de inovações onomásticas que chamarei de nomes crioulos. Todas essas pessoas transacionavam entre si num complexo fluxo de trocas materiais, políticas, matrimoniais e simbólicas, numa interpenetração muito rica e complexa de práticas sociais.

As informações referentes à distribuição etária reforçam a idéia de que o casamento não era uma prática cara aos moradores das povoações crioulas. Conforme mostra o quadro 4, havia 177 adultos, com mais de 21 anos. Sabendo-se que 14 eram casados, conclui-se que estes representam 8 por cento da população adulta. ${ }^{6}$ 
Quadro 4

Distribuição das idades segundo o sexo

$\begin{array}{lcccc}\text { Faixas etárias } & \text { Homens } & \text { Mulheres } & \text { Sexo desconhecido } & \text { Total } \\ \text { 0-23 meses } & 26 & 33 & 3 & 62 \\ 2-10 \text { anos } & 12 & 6 & 1 & 19 \\ 11-20 \text { anos } & 6 & 7 & 1 & 14 \\ \text { 21-30 anos } & 63 & 17 & 1 & 81 \\ \text { 31-40 anos } & 30 & 11 & 0 & 41 \\ \text { Mais de 41 anos } & 35 & 19 & 1 & 55 \\ \text { Idade não sabida } & 27 & 3 & 1 & 31 \\ \text { Total } & 199 & 96 & 8 & 303\end{array}$

\section{NOMEAÇÃO EM ÁFRICA E EUROPA}

Para examinar o trabalho da crioulização no que tange às práticas de nomeação, a primeira tarefa a enfrentar é discernir as estruturas subjacentes aos nomes nas vertentes civilizatórias que deram luz à sociedade crioula da Guiné - a européia (especialmente a sua versão portuguesa) e a africana (com destaque para as práticas de nomeação das sociedades costeiras da África Ocidental). ${ }^{7}$

Um exame rápido da literatura antropológica informa que as práticas de atribuição de nomes às pessoas são muito variadas embora sirvam a dois propósitos básicos: identificar os indivíduos concretos, tornando legível a paisagem humana composta de uma multidão de seres humanos (Scott et al. 2002: 4), e estabelecer as relações entre os indivíduos concretos e os grupos que transformam os primeiros em pessoas sociais. Assim, nomear é fazer a

[continuação] que então tinha cerca de 500 mil habitantes, os dados do serviço de registro civil indicam que houve apenas seis casamentos em 1943, 12 em 1944 e 40 em 1945. Em 1947, somente 24 pessoas se casaram em Bissau. Para Bolama, as informações são as seguintes: dois casamentos em 1946 e cinco em 1947. Fontes: para os dados de 1943 a 1945, ver Província da Guiné (1946); para os dados de 1947 e 1948, Província da Guiné (1948). Interessante também é comparar os dados sobre os índices de casamento da "população civilizada" no censo de 1950. Carreira (1959) nota que 20 por cento desse grupo de cerca de 8000 pessoas eram casados. Como a população era dividida entre brancos, mestiços e negros, vale ressaltar os índices para cada um desses grupos. Entre os brancos, 48 por cento da população haviam contraído matrimônio no registro civil, percentual que cai para 11 por cento entre os mestiços e para 5 por cento entre os negros.

7 Ao mencionar uma vertente civilizatória africana é bom deixar explícito que parto da idéia defendida por Kopytoff (1987) da existência de um ecúmeno sociocultural africano em que as várias sociedades africanas (em especial as da África Ocidental) compartilham atributos estruturais sociais e culturais, o que não quer dizer uma defesa de uma versão contemporânea e mal disfarçada da velha idéia difusionista da cultura como um conjunto de traços exteriores e observáveis. Assunto quente, de cujo desenvolvimento sou obrigado a me abster para não ir além do que me propus fazer. 
individuação e assinalar uma posição no sistema de relações sociais (a família, a linhagem, o clã, a localidade, a casta, o Estado) ${ }^{8}$

Em todos os cantos, e não somente nas sociedades não-européias, uma pessoa tem vários nomes, sendo chamada de muitas formas segundo o contexto de uso, a posição do endereçado e a de quem endereça. No Brasil contemporâneo ela pode ser endereçada pelo nome completo de registro, pelo prenome ou nome pessoal, pelo(s) nome(s) de família (sobrenome), pelos (vários) apelidos ou alcunhas, títulos e por termos apostos ao nome formal (e que dele fazem parte) como um marcador de relações, mas que podem acabar se tornando um meio de individuação (as partículas tecnonímicas como Sobrinho, Neto e Júnior). E essa variedade pode ainda ser combinada de várias formas, algumas gramaticais, outras nem tanto. Não são incomuns combinações em que títulos ou alcunhas são agregados ao nome formal ou a parte dele e ganham alguma permanência, mesmo em contextos de usos formais ou oficiais. O caso mais evidente é o do presidente Luiz Inácio Lula da Silva. No universo da vida política, outros casos confirmam a gramaticalidade dessas associações, como os dos deputados "Professor Luisinho" e "Doutor Rosinha". O mesmo acontecia, como se verá, na Guiné colonial.

Nas sociedades nacionais que se conformaram segundo o modelo europeu do Estado-nação, o nome formal, assentado no registro civil, tem assumido tão grande relevância que ofusca e enclausura o uso dos outros nomes à esfera das interações regionais em que o nomeado não atua tanto como um indivíduo anônimo e igual (o cidadão), mas, antes, como pessoa pertencente a este ou aquele grupo primário (família, grupo de amigos, entre outros). Tal predominância do nome oficial é produto de uma longa história de estabilização dos nomes pessoais, especialmente da fixação pela lei dos modos de se herdar os sobrenomes. Juntamente com a criação de cadastros de propriedade, a realização de censos populacionais, o estabelecimento de um sistema racional de medidas e a criação de uma moeda nacional, a obrigatoriedade do registro civil e as regulamentações das práticas de nomeação implicaram um crescente controle do Estado sobre a vida das pessoas. Como tendência geral compartilhada por muitos Estados-nações europeus, essas regulamentações colocaram obstáculos ao uso de nomes diferentes daquele que foi assentado no registro civil em contextos oficiais, isto é, nas relações do indivíduo com o Estado e suas instituições. ${ }^{9}$ Porém, a ação classificadora dos Estados europeus e seu empenho, por um lado, em elaborar uma forma de nomeação estável e sem ambigüidade e, por outro, em apagar as práticas incompatíveis com o novo modelo não foi

8 Para um exame dos nomes como uma questão da atividade classificatória humana, ver Lévi-Strauss (1976: caps. 6 e 7).

9 Sobre o processo de estabilização do patronímico na Europa, consultar Scott et al. (2002); sobre as regulamentações francesas, ver Noiriel (2001). 
absolutamente avassaladora e ainda encontra alguma resistência nas bordas da sociedade: nas comunidades rurais e entre os grupos marginalizados das periferias urbanas. ${ }^{10}$

De modo aproximativo, o paradigma europeu da nomeação toma a forma de uma cadeia sintagmática em que estão articulados dois ou mais elementos oriundos de séries paradigmáticas distintas (a dos prenomes e a dos sobrenomes). As duas séries paradigmáticas são constituídas por um número finito de elementos.

No que se refere à primeira série, em Portugal e outros países europeus o conjunto foi constituído lentamente pela tradição. Porém, conforme o nome oficial de registro foi ganhando preponderância sobre as outras formas de nomeação e a ação do Estado foi alcançando as comunidades mais distantes do poder central, o conjunto dos prenomes passou a ser fixado com maior rigor nos livros onomásticos. Assim, diferentemente de países do Novo Mundo, onde por razões variadas a cultura revelou uma grande inventividade na criação de prenomes, o paradigma dos prenomes em Portugal é formado por um pequeno número de elementos. ${ }^{11} \mathrm{Na}$ realidade, essa série se subdivide em duas, uma de prenomes masculinos e outra de femininos, apesar de alguns elementos serem ambíguos, pertencendo às duas subséries. A origem dos elementos da série é variada, destacando-se a hagiologia e os textos sagrados do cristianismo (a Bíblia em especial). Em si, os elementos constituintes básicos carregam pouco ou nenhum significado referencial que seja compartilhado por toda a comunidade, sendo que a maior freqüência relativa de um ou outro prenome em determinado período tem mais a ver com fatores conjunturais como a moda. Isto, porém, não quer dizer que os prenomes não tenham valor semântico, mas simplesmente que eles evocam mais do que significam e que as evocações e associações que eles desencadeiam são limitadas por fatores regionais, de classe, étnicos, ocupacionais e outros. ${ }^{12}$

10 Como exemplo, remeto ao trabalho de Zonabend (1977) sobre a nomeação entre os camponeses franceses na década de 1970 .

I 1 Dois comentários. Primeiro, parece que atualmente em Portugal as famílias têm sido mais inventivas na atribuição de prenomes do que foi no passado, atribuindo aos filhos nomes que não fazem parte do paradigma estabelecido na tradição, especialmente entre as classes populares. Consultar Pina Cabral (2003:130-132) para uma abordagem do conservadorismo português na atribuição dos prenomes e das recentes mudanças ocorridas nos ambientes urbanos. Resta conhecer etnograficamente como o Estado, através dos funcionários da conservatória do registo civil, tem reagido ao crescimento e inventividade na série paradigmática dos prenomes. Segundo, na falta de informações sobre a verdadeira dimensão dessa série em Portugal, tomo por empréstimo a informação veiculada por Scott et al. (2002: 7) que 90 por cento da população masculina tinha oito prenomes na Inglaterra do século XVIII: John, Edward, William, Henry, Charles, James, Richard e Robert. Como se verá a seguir, a série dos prenomes era maior na parte lusitanizada da Guiné colonial, mas mesmo assim era pequena, comparativamente aos paradigmas africanos.

12 Parece que na zona rural os nomes podem evocar sentidos pejorativos, associando seus portadores a determinados traços de caráter, como mostram as quadras: Antão/guardava ovelhas/ [continua] 
O paradigma dos sobrenomes também é formado por um pequeno número de elementos. No passado, ainda sem ter valor patronímico, grande parte desses nomes pertencia a cinco grandes categorias: espécies naturais (Lobo, Coelho, Carvalho), toponímia (Lisboa, Évora), ocupação (Ferreira, Cutileiro), alcunhas ou apelidos (Bigode, Careca) e filiação (Henriques, Fernandes). ${ }^{13}$ Uma outra característica dos elementos constituintes da série dos sobrenomes é que elementos reconhecidos como pertencentes à série dos prenomes podem migrar para ela. Na Guiné colonial, mas também em Portugal e outras sociedades da zona lusófona, um prenome comum como Pedro pode ser passado de pai para filho em várias gerações até assumir o papel de sobrenome herdado. A tendência geral que operou na série dos sobrenomes na tradição européia mostra que, uma vez estabilizados pela ação do Estado através da herança, isto é, transformados em nomes de família com valor legal, eles perderam a capacidade de portar significação referencial, tendo apenas o valor geral de indicar relações de pertencimento entre o indivíduo nomeado e o grupo familiar ao qual pertence. E se ainda têm algum poder de evocar associações, como acontece quando se associam certos sobrenomes a determinados grupos sociais, em geral dos estratos superiores, isso se deve muito mais à morfologia da cadeia sintagmática, isto é, às formas de encadeamento, do que ao valor semântico dos termos em si. E mesmo assim esse poder evocativo é relativamente instável e limitado ao contexto de uso.

$\mathrm{Na}$ tradição portuguesa, a articulação dos elementos das duas séries paradigmáticas para a constituição do nome formal é empiricamente variável, mas as variações se dão dentro dos limites estabelecidos pelas regras que presidem o sintagma. A natureza dessas regras é dupla, legal e jural. O limite externo de variação é dado no plano legal, que estabelece limites amplos, diga-se, para a escolha dos sobrenomes. Porém, a prática comum dos portugueses é orientada por uma norma não escrita, tomada como obrigatória, que impõe limites mais estreitos às práticas de nomeação.

Orientados por essa "norma" jural, a cadeia sintagmática que resulta nos nomes formais toma a seguinte forma geral: um ou mais termos oriundos da série paradigmática dos prenomes, seguida de um ou mais termos oriundos da série dos sobrenomes. O elemento que marca o sexo é o primeiro prenome,

umas suas/outras alheias. Ou então: "Oh Rita/caganita/quando mija/vai de bica." Estas e outras tantas que exprimem chascos pessoais ligados ao indivíduo estão publicadas em Braga (1995 I: 101-102).

13 Ver Caplan (2001: 53-54). É verdade que a tradição portuguesa não deixou, como a inglesa, marcas tão claras da transformação de nomes ou expressões que dizem respeito à filiação cristalizadas nos sobrenomes, como é o caso dos Williamson e dos Johnson. Porém, patronímicos como Henriques ou Fernandes atestam o trabalho da filiação na constituição do paradigma dos sobrenomes. Portugal também não é pródigo no uso de partículas tecnonímicas para constituição do nome formal como Júnior, Filho e Neto, embora isso seja relativamente comum na tradição lusófona, além-mar. Na tradição portuguesa parece que a ação da filiação se mostra mais em práticas como a de atribuir ao filho o nome formal do pai ou parte dele (cf. Pina Cabral 2003: 132) ou nos usos de patronímicos (já cristalizados como tais) na forma diminutiva. 
devendo ser escolhido da subsérie de prenomes próprios dos homens ou mulheres, conforme o caso. Se a pessoa tem dois prenomes, o segundo elemento pode ser retirado de qualquer uma das subséries. Assim, é gramatical que um homem se chame João Maria e uma mulher Maria João, mas o inverso é não gramatical. A seguir, são encadeados os sobrenomes que, pela "norma" jural, devem ser herdados. A preponderância de uma ideologia patrilinear faz com que o sobrenome paterno esteja quase sempre presente na cadeia sintagmática do nome oficial. A ausência do sobrenome materno não é incomum, mesmo no caso de crianças nascidas de casais estáveis, cuja união foi reconhecida pelo Estado através do casamento civil. Nos meios urbanos é comum a herança dos patronímicos (os sobrenomes paternos) da mãe e do pai. As práticas de nomeação sugerem que a ordem dos patronímicos seja primeiro, logo após o prenome, o patronímico materno e depois o do pai. ${ }^{14}$ Variações podem ocorrer como, por exemplo, a agregação de sobrenomes dos avós e bisavós que não foram herdados pelos pais, o desmembramento de sobrenomes duplos ou, o que é mais comum, a fusão de sobrenomes simples. No entanto, essas variações raramente significam um rompimento com a regra geral de encadeamento.

Em África, nos ensina Bastide (1981: 43), a multiplicidade do indivíduo, com seus diversos laços de pertencimento social, encontra expressão nos diversos nomes que ele recebe. Alguns são dados logo após o nascimento, outros adquiridos em fases diferentes da vida, conforme o caráter, a idade, os cargos que ocupa e o contexto social em que vive. Em todo caso, a multiplicidade de nomes em África não deve ser tomada como um traço diferenciador das práticas de nomeação européias, pois também na Europa as pessoas são chamadas de várias maneiras no decorrer da vida. A diferença é que lá uma das formas de nomeação, o nome oficial inscrito no registro civil, ganhou uma saliência que não encontra correspondência em África. E longe das metafísicas razões culturais tão invocadas para marcar diferenças, a explicação é sociológica e tem a ver basicamente com o fato de o poder estatal em África, e a lógica que o orienta, não ter subsumido os poderes locais e suas lógicas.

Passarei em revista as formas mais comuns em uso na África Ocidental (com destaque para as sociedades da Guiné), não para encontrar um modelo africano de nomeação, mas para revelar seus atributos que têm valor explicativo (pela comparação) para a análise das formas de nomeação encontradas no meio crioulo da Guiné-Bissau. Meu ponto de partida é o da variedade de práticas e da multiplicidade de nomes. Conforme nota Thomas (1959: 190), se referindo às populações diolas do sul do Senegal e norte da Guiné-Bissau, uma pessoa pode ter até uma dúzia de nomes durante sua vida. Alguns são abandonados, outros permanecem; alguns são públicos, outros são secretos ou de circulação muito

14 No Brasil, a ordem contrária, pela qual o patronímico da mãe se localiza em último lugar, é tomada como uma forma de nomeação espanhola. 
restrita. Não há uma regra única, quanto à forma de atribuição dos nomes. Em algumas sociedades, pelo menos um dos vários nomes de uma pessoa é a ela outorgado em elaboradas cerimônias de imposição de nome que incluem sacrifícios e a presença de especialistas. Este é o caso, entre outros, da cerimônia kun-di entre os bambaras (Ba 1981: 184), dos três ritos de imposição do nome às crianças dogons (Dieterlen 1981: 224-225), da cerimônia de nomeação dos sabés chamada eéko (Marti 1981: 323), e do rito indeeri (também conhecido no Kaabu como pembungal) dos fulas (Riesman 1998: 58-61; Brito 1955: 600, 602). Já na maioria das sociedades costeiras da Guiné, a imposição do primeiro nome à criança não passa pela elaboração cerimonial. Este é o caso dos papéis (Einarsdóttir 2000: 113), manjacos (Menezes 1928: 13), cunantes (Pimentel 1927: 10), felupes (Thomas 1959: 190) e também dos bijagós (Santos Lima 1947: 92). ${ }^{15}$ Mais tarde na vida, durante os rituais de iniciação à vida adulta, as pessoas mudam mais uma vez de nome. É o caso do rito de iniciação masculina nubir kusina entre os bijagós (Duquete 1983: 88; Henri 1994: 124-125; e Quintino 1969: 910) e da iniciação às sociedades secretas Poro e Sande entre os mendes da Serra Leoa (Little 1967: 117, 125; MacCormack 1979: 32).

É muito difundida nas sociedades africanas a prática de não dar o nome à criança tão logo ela nasça, havendo ou não cerimônia de imposição de nome. Entre muitos povos é comum que se aguarde uma semana ou um pouco mais para a imposição do primeiro nome da criança, mas há casos em que a pessoa fica até o desmame (dois anos ou mais) sem ter um nome fixo, como sucede entre os bijagós (Quintino 1969: 910). Essa demora está associada à crença generalizada de que a nomeação logo após o nascimento ameaça a sobrevivência dos recém-nascidos. Acredita-se que os espíritos malignos têm uma preferência especial em atacar as crianças pequenas. Um dos modos de evitar isto é retardar a nomeação, pois a falta de nome faz com que essas entidades tenham dificuldade em reconhecer sua possível vítima, sendo assim uma das formas usadas para ludibriá-los. Outra forma de enganá-los é atribuir nomes repulsivos às crianças. Neste caso, o repertório é muito grande. Entre outros, destaco Funtum-ó (nome mandinga significando trapo), Koranhe (palavra bijagó para estrume), Kedacta (percevejo em balanta), Bâbâ (burro em fula), Pekers (palavra papel para morto) e Afili-djê (palavra mandinga para desprezado, abandonado). ${ }^{16}$

15 Noto a perspectiva discordante de Carreira e Quintino (1964: 83), que afirmam que o rito de imposição do nome é comum a todos os povos da Guiné, consistindo em rapar a cabeça da criança e aproveitar o cabelo cortado para a confecção de amuletos protetores. Em que pese a eventual correção dessa posição, vale notar que ela só se aplicaria ao primeiro nome que a criança recebe. Os autores nada dizem sobre os outros nomes que a pessoa receberá no decorrer de sua vida.

16 O trabalho de Carreira e Quintino (1964; 1966) lista uma enorme série de nomes repulsivos. Crenças e superstições sobre os perigos que correm as crianças recém-nascidas de serem atacadas por espíritos malignos e bruxos não são exclusividade das sociedades africanas. Adolpho Coelho (1993, I: 459) nos lembra que no mundo rural português do fim do século XIX as crianças ainda não [continua] 
Na tradição européia os nomes formais assentados no registro civil são públicos e ali parece ser um contra-senso a idéia de nomes privados ou secretos. ${ }^{17}$ Em algumas sociedades africanas os nomes secretos ou privados não representam uma absurdidade. Entre os tallensi, é comum que uma pessoa tenha ao menos dois nomes. Um é público e está associado ao estado de espírito que prevalecia na família ou a algum evento marcante que teve lugar na época do nascimento da criança, prática muito difundida em todas as sociedades africanas. O outro é privado, conhecido e usado exclusivamente pelos membros da família. Ele se refere ao ancestral guardião da pessoa e é uma forma de marcar o laço de dependência específica que o nomeado tem para com o seu guardião. É por meio desse nome que o indivíduo se torna um ser único, distinto dos demais em sua família e grupo de descendência (Fortes 1981: 312). As formas de apelação eékì entre os sabes também têm algo de restrito. Os eékì são nomes específicos e muito individualizados que evocam traços do caráter e do físico da pessoa. Conforme aponta Marti (1981: 324), não se trata propriamente de um nome secreto, mas nunca deve ser divulgado de modo leviano e ordinário, pois é parte intrínseca da pessoa. Entre os diolas, os nomes são geralmente públicos, mas há nomes secretos e severas restrições de uso público em casos específicos. Thomas (1959: 175-176, 190) relata que quando são entronizados os reis devem escolher um novo nome, compatível com sua nova função, e esse nome só pode ser pronunciado em circunstâncias bem determinadas pelo costume.

A variação também atua na diferenciação entre nomes masculinos e femininos. Via de regra, os povos islamizados como os fulas e mandingas têm nomes distintos para homens e mulheres, como Braima, Balabá, Djankubá e Ansumane para os primeiros e Cadija, Fatumata, Satu e Iamá para as segundas. Mas, como vimos para o caso português, também há entre esses grupos uma série razoável de nomes que são usados indistintamente por homens e mulheres, como Maundé, Teném, Juma, Bambé e outros (Brito 1955: 603). Nas sociedades costeiras, a série paradigmática dos prenomes tem mais elementos que não marcam a diferença entre os sexos, podendo ser usados por rapazes e moças, como nota Einarsdóttir (2000: 113) para os papéis de Bissau.

Em Portugal é comum que a pessoa receba o nome (ou parte dele) dos pais ou avós. Isso também acontece em África. Porém, a prática mais comum para associar alguém aos membros das gerações ascendentes do grupo de parentesco

[continuação] batizadas eram chamadas de Custodinho ou Custodinha, Inácio ou Inácia, segundo o sexo, como forma de evitar que fossem embruxadas.

17 O mais próximo que se tem de nomes secretos em Portugal está nas formas de nomeação não controladas pelo Estado: nas alcunhas de uso restrito aos grupos primários como a família e eventualmente nos nomes usados pelas pessoas como membros de sociedades fechadas e exclusivistas. Não são exatamente nomes secretos, mas, antes, nomes invisíveis para o Estado e de uso restrito, sujeitos a alguns tabus. 
é dar à pessoa o nome de um parente morto ou de um ancestral ou ainda que remeta a estes. No primeiro caso, trata-se de uma homenagem, mas ela só é feita nos casos em que houve uma "boa morte", isto é, quando o parente homenageado não morreu tragicamente ou muito jovem. O segundo caso está associado à crença na reencarnação e na ação permanente dos ancestrais na vida social. Muito difundido na África Ocidental, esse sistema de crenças opera freqüentemente nas práticas de nomeação através da imposição de nomes como Babatundé, que significa "o avô volta", dado à criança que é identificada como a reencarnação de um ancestral (Marti 1981: 323).

Isto me leva ao último atributo das práticas africanas de nomeação que quero reter. Diferentemente das práticas de nomeação européias, em que o prenome é um termo arbitrário usado para localizar um sujeito no interior de um grupo (uma família, uma localidade ou uma nação), sendo portador de pouca (ou nenhuma) significação referencial, os nomes pessoais africanos tendem a veicular sentidos referenciais e, em muitos casos, místicos, dando acesso direto à alma da pessoa. Como expressa bem um ditado felupe (um subgrupo diola) anotado por Thomas (1959: 175), é a palavra que faz o fetiche. Nessas circunstâncias, dizer o nome é o mesmo que agir sobre o espírito da pessoa. Por isto, os recém-nascidos, frágeis e indefesos, permanecem muito tempo sem ser nomeados ou recebem nomes que enganam os espíritos malignos.

Insisto: os nomes pessoais africanos têm uma carga semântica elevada, tanto em sua dimensão referencial como no nível pragmático da evocação e da indexicalidade. ${ }^{18}$ Característica extremamente difundida na África Ocidental é a dos nomes pessoais dizerem respeito aos traços físicos ou da personalidade do nomeado. Por exemplo, entre os papéis da ilha de Bissau uma pessoa pode-se chamar Uit (palavra papel para touro) por ter o caráter de um lutador. Nomes diola como Elhug enyab, Ehiki bān ou ainda Kalu kumise (literalmente, "tu és belo em toda parte que aparece", "tu que tens o cu de um elefante" e "espaço pequeno") se referem ao aspecto físico dos nomeados. Palavras que expressam virtudes e defeitos, como conversador, trabalhador, guloso e preguiçoso, servem para nomear as pessoas em várias sociedades tradicionais da Guiné. Nisto os nomes pessoais africanos são semelhantes aos apelidos ou alcunhas no Brasil, que são signos motivados pela aparência física ou atributos da personalidade

18 Alguma cautela se faz necessária a esse respeito. Apesar de os nomes africanos serem portadores de sentidos referenciais, algum cuidado deve ser tomado no esforço por buscar os sentidos dos nomes. Conforme ressalta Henri (1994: 125), os investigadores portugueses da época colonial nunca chegaram a um consenso mínimo quanto aos sentidos dos nomes. A própria autora nota que, ao buscar desvelar junto aos bijagós os sentidos dos seus nomes, os próprios ilhéus ofereciam respostas diferentes às suas indagações. Acredito que essa polissemia indomada não resulta somente das deficiências da antropologia colonial. Não é tampouco produto do absurdo que seria o desconhecimento nativo da cultura nativa. A verdade é que a antropologia entra em terreno muito pantanoso quando a ênfase do trabalho antropológico se desloca do exame da ação social para uma obsessão metafísica com a exegese cultural. 
de seus portadores. ${ }^{19}$ As circunstâncias do nascimento também são tematizadas na nomeação. Assim, os filhos espúrios nascidos de relações adúlteras podem se chamar, entre os fulas, Alahinde, Udô ou Fatu, que significam respectivamente "sem nome", "palha" (gerado na palha) e "ilegítimo". Do local onde a mãe pariu pode estar a inspiração para nomes como Bambê (quintal), Djimbã (alpendre) Nhobum (celeiro). Sair do ventre da mãe pelos pés e não pela cabeça motiva nomes como Igé entre os iorubas. A situação da família, a história dos partos anteriores e os sentimentos gerados por essa situação ganham expressão numa variedade de nomes. Por exemplo, uma mãe que teve muitos abortos e natimortos pode nomear o filho que sobrevive de Otokonomo (o único). Um parto trabalhoso motiva nomes como Bố, Meta (demorado), Fada (esperado), Uludô (o que chora). Batada é um nome que indica que a mãe teve que esperar muito para ter o primeiro filho. Se a criança cunante nasce quando os estoques de alimentos da família estão baixos, depois de um ano ruim de chuvas, ela pode se chamar Col (fome).

O poder de significação referencial e evocativa dos nomes africanos pode ser observado em várias práticas. Talvez a mais visível esteja associada aos nomes de família, que são, em geral, nomes clânicos, muitas vezes de natureza totêmica. Nessas circunstâncias, o nome aponta diretamente para a espécie escolhida como totem e o seu proferimento é regulado por regras equivalentes às que balizam a relação com o totem. Em conjunto, os nomes de família funcionam como um mapa mental que opera na regulação das relações sociais, prescrevendo ou proibindo casamentos, a participação em ciclos rituais, o acesso a cargos políticos, veiculando histórias familiares, subordinando ou incorporando seus portadores a determinados grupos sociais e evocando instituições culturais como as relações jocosas. ${ }^{20} \mathrm{O}$ uso dos nomes de família (linhagem ou clã) tem forte componente indéxico. Em geral, o nome de família é formalmente atribuído ao sênior do grupo, ao cabeça da linhagem, mas a identificação do nome com a pessoa se estende a todos os membros do grupo. Kopytoff (1971) mostra que entre vários povos africanos a pessoa se refere à sua linhagem e à história dela, no passado, como "eu" e que o uso do nome da linhagem para se referir aos indivíduos concretos varia segundo o contexto. Assim, uma criança pode ser endereçada pelo seu nome de linhagem, desde que não esteja presente nenhum membro mais velho do grupo. No momento em que alguém mais velho entra em cena, o nome de linhagem passa então a ser usado para se referir a ele. Essas formas de uso sugerem que os nomes de família são índices: ao contrário dos nomes, que se referem aos seres (individuais ou coletivos), eles ainda são pronomes, sem referencial fixo.

19 Sobre os apelidos ou alcunhas numa pequena cidade do interior brasileiro, ver Couto (1987/1988).

20 Ver o estudo de Mann (2002) sobre os nomes familiares (jamu) no mundo mande. 
Um dos desdobramentos da implantação do Estado colonial em África foi o esforço para domesticar as práticas de nomeação indígenas e adaptá-las às formas européias. ${ }^{21}$ Por causa desse esforço, muitas vezes os nomes clânicos africanos em uso nos centros urbanos perderam parte de sua carga semântica, transformando-se em sobrenomes sem relação com as espécies a que se referiam..$^{22} \mathrm{O}$ crescente registro escrito das identidades e a parafernália de identificação sob a forma de bilhetes de residência e identidades indígenas, passes e permissões para viagens e trânsito no meio urbano operaram no sentido de dar maior rigidez às formas de nomeação e dificultar a mudança de identidade (Amselle 1990: 203). Porém, o poder colonial nunca foi esmagador e a frágil hegemonia criada sempre foi contestada. No que se refere aos nomes, o mundo colonial africano tinha muitos espaços francos em que era possível e fácil para as pessoas rejeitar e mudar seus nomes de família e dar asas à imaginação criando nomes expressivos como Oumarou ça m'en fous, Poor no friend, Gin bottle e Money palaver. ${ }^{23}$ Nesses espaços as pessoas rejeitavam, mudavam e inventavam dos nomes como uma forma de lidar com as estruturas de dominação local e colonial, seja para delas escapar, para se subordinar ou para ser a elas incorporados (Mann 2002: 317-318).

\section{O TRABALHO DA CRIOULIZAÇÃO}

O processo de crioulização diz respeito, por um lado, a uma espécie de compromisso (lingüístico, social e cultural) alcançado por grupos provenientes de vertentes civilizatórias diferentes, que vivem em estreita convivência e numa relativa simetria de poder, pela qual nenhum deles tem condições objetivas de alcançar uma dominação plena ou mesmo uma hegemonia. Por outro, tem a ver também com a reprodução desse compromisso, sua dinâmica interna e com a conseqüente variabilidade (sincrônica e diacrônica) das formas cristalizadas nele e por ele. Nessa última seção quero analisar o estágio em que esse compromisso se encontrava no final do século XIX.

21 Chamo a atenção para o fato de que em 1948 o governador colonial ainda sentia necessidade de conclamar os administradores de circunscrição a agir de modo a fazer com que as famílias dessem nomes portugueses aos filhos. Juntamente com a busca por diminuir a poliginia através da tributação das famílias poligínicas, com as tentativas de implementação do Código de Registo Civil, a conclamação do governador no tocante às práticas de nomeação era um elemento adicional no esforço por controlar e identificar os sujeitos e cidadãos no Estado colonial. Sobre as tentativas de diminuir a poliginia na Guiné, ver Carreira (1951; 1961). Consultar também Hunt (1991), para uma comparação com o antigo Congo Belga.

22 Nisto não são tão diferentes de patronímicos portugueses como Lobo, Coelho, Pinto e Pereira, que, usados como sobrenomes, pouco reportam às espécies vegetais e animais.

23 O primeiro nome é de um soldado desmobilizado do Futa-Djalon (cf. Mann 2002: 317), os outros são nomes adotados por homens mende que migraram para os centros urbanos (cf. Migeod 1917: 45). 
O corpus analisado contém 496 indivíduos nomeados com uma série de 207 prenomes. Se fossem igualmente distribuídos, o corpus examinado teria pouco mais de dois indivíduos para cada prenome. Isto significa que o paradigma em operação na Guiné tinha muito mais elementos do que o paradigma equivalente europeu. Contudo, quando se olha para a sua distribuição, nota-se que a série é constituída de 162 prenomes cristãos (majoritariamente portugueses), $4 \mathrm{l}$ africanos e quatro que chamarei de crioulos, por representarem compromissos resultantes de interferências culturais ou empréstimos semânticos. Quando se toma a série africana, verifica-se que os 41 termos nomeiam 42 pessoas, o que significa que somente um termo (Malam) se repete. Como os quatro prenomes crioulos não se repetem, tem-se então que os 162 nomes cristãos nomeiam 449 indivíduos, numa distribuição muito desigual. Os nove prenomes masculinos mais comuns na série nomeiam 187 indivíduos ou 40 por cento do corpus. São eles: António (com 42 entradas), José (28), Manuel (27), João (22), Pedro (18), Domingos (16), Joaquim (14), Francisco (13) e Luiz (7). A subsérie de prenomes femininos tem menos picos de concentração, sendo que os quatro mais comuns nomeiam 36 pessoas: Maria (com 21 entradas), Domingas, Isabel e Luiza (com cinco entradas cada). O quadro 5 indica a distribuição dos prenomes cristãos e africanos segundo sua freqüência.

A distribuição dos prenomes africanos e cristãos segundo os locais de nascimento é mostrada no quadro 6. Dos sete indivíduos africanos oriundos de outras colônias européias, quatro tinham filiação ignorada, perfazendo um total de 10 nomes. Destes, três tinham prenomes oriundos da tradição africana (Samba, Demba e Bakar), representando 30 por cento do total. O contingente oriundo de Angola é de 47 pessoas, sendo 30 com filiação ignorada. Das 54 pessoas nomeadas, 21 tinham prenomes africanos e 33 cristãos. A contribuição africana para o grupo angolano é de 38 por cento, um pouco maior do que a

Quadro 5

Freqüência relativa dos prenomes

$\begin{array}{cccc}\text { Freqüencia } & \begin{array}{c}\text { Nomes } \\ \text { masculinos }\end{array} & \begin{array}{c}\text { Nomes } \\ \text { femininos }\end{array} & \begin{array}{c}\text { Nomes } \\ \text { africanos }\end{array} \\ 42 & 1 & 0 & 0 \\ 28 & 1 & 0 & 0 \\ 27 & 1 & 0 & 0 \\ 22 & 1 & 0 & 0 \\ 21 & 0 & 1 & 0 \\ 18 & 1 & 0 & 0 \\ 16 & 1 & 0 & 0 \\ 14 & 1 & 0 & 0 \\ 13 & 1 & 0 & 0 \\ 7 & 1 & 0 & 0 \\ 5 & 2 & 3 & 0 \\ 4 & 2 & 3 & 0 \\ 3 & 8 & 5 & 0 \\ 2 & 21 & 10 & 1 \\ 1 & 59 & 38 & 40\end{array}$


Quadro 6

Percentual dos nomes segundo as tradições de nomeação e da filiação ignorada

$\begin{array}{ccccc}\text { Local } & \text { Nomes cristãos } & \text { Nomes africanos } & \text { Nomes crioulos } & \text { Filiação ignorada } \\ \text { de nascimento } & \% & \% & \% & \% \\ \text { Cabo Verde } & 100 & 0 & 0 & 25 \\ \text { Europa } & 100 & 0 & 0 & 28 \\ \text { Portugal } & 100 & 0 & 0 & 35 \\ \text { Guiné } & 86 & 11 & 3 & 27 \\ \text { África não } & 70 & 30 & 0 & 57 \\ \text { portuguesa } & 62 & 38 & 0 & 63 \\ \text { Angola } & & & & \end{array}$

dos africanos das colônias vizinhas. Quando se soma às 162 pessoas nascidas na Guiné os 117 pais cujos nomes eram conhecidos, temos um conjunto de 279 indivíduos com 140 prenomes cristãos, 18 africanos e quatro crioulos (Retranca, Chuva, Bula e Fará). Os nomes africanos correspondem nesse grupo a 11 por cento do total. A lista das 43 pessoas nascidas em Cabo Verde menciona 32 relações de filiação, de modo que o grupo de indivíduos com nomes registrados é de 75 indivíduos, todos eles com nomes cristãos. Aos 34 nascidos em Portugal se somam outras 20 pessoas, que aparecem como progenitores. Todos tinham nomes cristãos.

Os dados do quadro 6 sugerem que as tradições de nomeação se faziam presentes de maneira diferenciada entre os vários grupos que compunham a sociedade crioula de Bissau e Bolama, embora houvesse uma predominância de nomes cristãos. E apesar de não estar numa variação linear, há uma consistente correlação negativa entre a tradição cristã de prenomes e o percentual das filiações ignoradas. Isto não causa surpresa e sugere que a predominância da tradição de nomeação cristã caminha junto com o aumento do controle do Estado sobre a vida dos indivíduos. ${ }^{24}$ Elementos conjunturais ajudam a

24 No final do século XIX, os estrangeiros na Guiné eram obrigados a ter um documento chamado de bilhete de residência. Isto se apreende de uma portaria provincial de 1891. Depois da derrota na guerra contra os papéis de Bissau, os vitoriosos prestaram um auto de submissão aos derrotados, num verdadeiro ritual de inversão muito corriqueiro nas relações entre portugueses e africanos na Guiné. Por esse auto, os grumetes que quisessem trabalhar para os negociantes de Bissau deveriam portar um bilhete de identidade fornecido pela autoridade da povoação, que tinha os mesmos moldes dos bilhetes de residência obrigatórios para os estrangeiros. Nova portaria nesse sentido foi emitida em 1894, depois de outra guerra contra os papéis. E um ano depois, como muitos grumetes não tinham solicitado o seu documento, o governo prorrogou o prazo para sua execução. A distinção jurídica e formal da população entre indígenas e civilizados só veio a acontecer mais tarde, em 1917, e a introdução da caderneta indígena (para os africanos das aldeias) [continua] 
explicar a não linearidade da variação. Em primeiro lugar, parecem contraditórios o alto índice de filiação ignorada entre os angolanos, já que eles também eram estrangeiros, e o baixo índice entre os guineenses. A imensa maioria dos angolanos estava na Guiné como soldados do batalhão do exército colonial. A falta de disciplina, o relaxamento, o descumprimento das ordens superiores e o estado de quase permanente insubordinação desse grupo, tão ressaltados na literatura colonial, sugerem que, se o governo provincial era impotente para controlar a conduta na caserna, era ainda muito mais para conhecer e registrar suas identidades pessoais. Recrutados num ambiente social em que as relações familiares e as práticas de nomeação eram orientadas por outra lógica e valores, em larga medida desconhecida pelas autoridades coloniais em Angola, o que dizer do conhecimento detido pela Junta de Saúde da Guiné tão precariamente organizada. Por outro lado, os altos índices relativos de filiação reconhecida (e de alguma forma registrada) dos guineenses das povoações crioulas parece ter mais a ver com o efeito da proximidade do que com o controle estatal sobre a vida familiar. Em ambientes pequenos como as cidades crioulas, onde quase todos se conheciam e se relacionavam por meio de interações face a face, não era absolutamente necessário que o Estado desenvolvesse complexas maquinarias de controle para que informações como a da filiação nas listas de movimento obituário fossem conhecidas e publicadas.

Penetramos com isto numa faceta peculiar do processo de crioulização. Os nomes publicados pela Junta de Saúde pertenciam à esfera oficial da vida em sociedade. Porém, a dimensão oficial no universo crioulizado da Guiné era (e ainda é) muito menos dependente da organização do Estado em instituições burocráticas que visam realizar o mais completa e racionalmente a atividade mista de classificação e controle da população, como o registro civil. Ontem e hoje na Guiné o Estado é patrimonial e suas relações com a população têm sido caracterizadas pela pessoalidade e pela proximidade de seus agentes com os cidadãos ou sujeitos, conforme a época. O esforço por montar um sistema de registro civil operativo em toda Guiné só foi proposto tardiamente e teve que enfrentar uma série de percalços antes de se tornar efetivo. Os primeiros esforços de adaptar na Guiné o Código do Registo Civil que prevalecia em Portugal resultaram em fragoroso fracasso. A imposição do assento definitivo do nome, através das certidões de nascimento tão logo a pessoa nascesse, encontrou resistência entre a população que acreditava que uma criança não pode ter nome até que ande, fale e coma sozinha. Não é gente e, pior, se for nomeada, pode ser detectada e comida pelos feiticeiros. Confrontados com tal tipo de crença, as autoridades tiveram que criar a figura do registro provisório, feito logo após o nascimento, que mais tarde, após o desmame, era substituído pelo registro 
definitivo, este sim com o nome (Carreira 1967: 43-46). E enquanto o Estado não tivesse condições de instituir a maquinaria necessária, a dimensão oficial da vida social era gerida através do idioma da pessoalidade e proximidade.

Também parece contraditório o fato de o índice de filiação desconhecida ser mais elevado entre os portugueses do que entre os cabo-verdianos e guineenses. Não disponho de informações sobre os estratos sociais de onde vinham os portugueses que residiam na Guiné nem sobre as regulações da identidade que vigoravam em Portugal no século XIX para avaliar melhor esse percentual. Porém, é necessário ter sempre cautela para não tomar como eterno aquilo que hoje se nos afigura universal. O elevado índice de filiação ignorada entre os portugueses na Guiné se explica, pelo menos em parte, pelo fato de que os mecanismos de identificação usados pelos Estados nacionais ainda não estavam consolidados no final do século XIX em Portugal. Evidências disto podem ser encontradas quando se desloca o olhar da série dos prenomes para a cadeia sintagmática que os articula com segundos nomes, tomados ou não como sobrenomes.

O modelo europeu dos nomes pessoais, tal como exposto na seção anterior, encontrava muitas exceções na Guiné colonial. Um dos casos que quero examinar diz respeito a uma instabilidade específica dos patronímicos: a sua ausência, pura e simples. É como se a cadeia sintagmática fosse constituída de dois conjuntos de termos, o dos prenomes seguido por um conjunto vazio. Dos 496 indivíduos nomeados, 85 pertencem sem qualquer ambigüidade a essa categoria e nove outros casos dela se aproximam. Isto representa cerca de 20 por cento do corpus examinado. A distribuição dos 85 casos segundo a nacionalidade e tradição de nomeação está revelada no quadro 7 .

\section{Quadro 7}

Nomes compostos de um só termo segundo o local de nascimento e as tradições de nomeação

$\begin{array}{ccc}\text { Origem } & \text { Freqüência } & \text { Tradição de nomeação } \\ \text { África não portuguesa } & 1 & 1 \text { Afr. } \\ \text { Europa } & 0 & - \\ \text { Portugal } & 1 & 1 \text { Crist. } \\ \text { Cabo Verde } & 2 & 2 \text { Crist. } \\ \text { Angola } & 29 & 7 \text { Crist.; } 22 \text { Afr. } \\ \text { Guiné } & 52 & 29 \text { Crist.; } 19 \text { Afr.; } 4 \text { Cr. }\end{array}$

O exame do quadro 7 revela que o conjunto de nomes cristalizados numa cadeia sintagmática formada por um só termo inclui todas as tradições de 
nomeação - a cristã ou européia, a africana e a crioula. E quando se considera os casos ambíguos, cresce o número de portugueses com esse padrão de nomeação. Portanto, com a exceção dos europeus não portugueses, todos os outros lugares de nascimento geraram pessoas com nomes formados por um só termo. A ausência de sobrenomes na constituição dos nomes, mesmo em sua dimensão oficial como os da Junta de Saúde, sugere em primeiro lugar que o Estado não tinha mecanismos para classificar com precisão e racionalidade nem para controlar os muitos "Antónios e Pedros só" que viviam em Bolama e Bissau. Segundo, o próprio registro dos nomes no movimento obituário indica que esse padrão de nomeação era satisfatório, funcionando a contento para estabelecer identidades pessoais de gente de proveniência variada no ambiente crioulizado das praças. Suspeito que sua eficiência está associada ao fato de os nomes serem portadores de significado referencial ou de poder de evocação, especialmente os nomes africanos e crioulos, tendo assim uma relação intrínseca com a pessoa.

Dos nomes africanos registrados nas listas de falecimentos, alguns são descritivos de situações sociais, de coisas e fenômenos do mundo natural e de traços da pessoa. ${ }^{25}$ Por exemplo, Metta é um nome mandinga dado às pessoas que demoraram muito para nascer. Umpone é um nome manjaco que significa rapariga impúbere. Dibá significa escuridão na língua mandinga. Outros estão associados com o desejo de ludibriar os espíritos malignos que comem as crianças. Nas listas encontra-se o caso de Duá, nome mandinga para o abutre, ave que muitos povos da Guiné consideram ser defeso de matar. O tabu e a repulsividade do animal que come os dejetos são características que afastariam os espíritos malignos e feiticeiros. Os quatro nomes crioulos registrados também são portadores de sentido referencial. Bula é o nome de uma região no território mancanha. O nome Chuva provavelmente foi escolhido para se referir às condições do tempo à época do nascimento, prática comum entre muitos povos da Guiné. Retranca possivelmente se refere a um traço de caráter de seu portador (pessoa fechada que reage com agressividade). Por fim, o mais dúbio, Fará: pode tanto ser um termo português expressando o desejo de seus pais, quanto a forma mandinga Farã, que nomeia o sétimo filho. No caso dos nomes crioulos, o trabalho da crioulização se deu no nível lexical. Manteve a estrutura profunda enraizada em valores e crenças e relexificou a camada de superfície, a forma lingüística. ${ }^{26}$

Como as pessoas tinham (e ainda têm) múltiplos nomes, em caso de ambigüidade, faziam como fazem ainda hoje: recorrem aos outros nomes, conforme o contexto de uso, ou lançam mão de marcadores muito difundidos como as

25 Deixo de lado os nomes dos angolanos por serem oriundos de uma outra região etnográfica africana.

26 Esta é uma forma de transformação muito comum nos processos de crioulização lingüística. Muitos sociolingüistas defendem que algumas das línguas crioulas faladas na costa ocidental da África e no Caribe (hoje vistos como crioulos de superestrato francês e inglês) são formas relexificadas de um antigo crioulo de base portuguesa falado em toda a região. Ver Couto (1996). 
partículas tecnonímicas. Nas listas de falecimento encontram-se registros de nomes como o de Manuel da Rosa. Trata-se de casos interessantes pela ambigüidade que portam. Este pode ser entendido como exemplo da ausência do sobrenome, sendo a locução "da Rosa" uma partícula tecnonímica que refere o Manuel em questão a uma Rosa que seria sua mãe, mulher ou companheira. Porém, o mero fato de o marcador estar inscrito no registro oficial dos falecimentos sugere uma tendência de estabilização do padrão europeu de nomeação que vinha se consolidando então sob a forma de um (ou mais) prenome e um (ou mais) sobrenome. O interessante, porém, é notar o trabalho da crioulização nesse caso, que oficializa e confere legitimidade a práticas que já não estavam mais em uso na esfera oficial da vida social européia, apesar de terem sido no passado práticas comuns, como atestam os patronímicos Williamson e Johnson, já de muito estabilizados e herdados.

O exame dos casos ambíguos conduzirá à análise das cadeias sintagmáticas com mais de um elemento funcional. Por ora quero reter os casos em que o nome oficial era constituído por mais de um termo, mas todos oriundos da série dos prenomes. Os casos mais simples são os dos soldados portugueses Manuel Joaquim, José Luís, Adrião José, José Maria e dos angolanos António Domingos, João Paulo, João Manuel e Júlio Manuel. Trata-se claramente de prenomes duplos em que o segundo termo é extraído do mesmo paradigma que originou o primeiro e não assume o valor funcional de sobrenome herdado. Dos sete casos mencionados, somente uma pessoa foi registrada como tendo filiação reconhecida, o soldado português José Maria, cujo pai se chamava Joaquim Coelho, nome que se conforma ao modelo português de dois termos, tendo o último o valor de sobrenome. Porém, tudo leva a crer que o modelo ainda não estava consolidado em Portugal, já que o filho não herdara o sobrenome paterno ou qualquer outro.

Caso mais complexo é do dos indivíduos chamados George Pedro e António Pedro, pai e filho respectivamente. Noto primeiro a forma inglesa do prenome desse madeirense, que indica a existência de fluxos e transferências entre as subtradições européias. Embora George, António e Pedro sejam termos pertencentes ao paradigma dos prenomes, o fato de o termo Pedro ter sido herdado pelo filho, sugere que ele passou a ter valor patronímico, o que está em consonância com as práticas de nomeação das camadas populares em Portugal. O fato de essas práticas de nomeação terem origem nas camadas populares e daí se difundirem para o restante da sociedade sugere a necessidade de reexaminar um entendimento implícito e muito difundido nas ciências sociais, de que as imitações, mimeses e apropriações têm como modelo as camadas superiores. ${ }^{27}$ Interessante também é o caso do comerciante Lourenço David, cuja

27 Esse consenso implícito, presente no pensamento ocidental desde as reflexões de Aristóteles sobre a mimese em sua Poética, tem sido compartilhado tanto por pensadores sofisticados como [continua] 
mulher se chamava Helena Benício Lourenço. Temos aqui um nome feminino formado por três prenomes, sendo que dois deles pertencem ao paradigma dos prenomes masculinos. O casamento produziu um movimento criativo em que o prenome do marido foi passado para a mulher, com valor de sobrenome.

Mais interessante ainda é olhar para a inscrição dos nomes tal como ela se dá nas listas de falecimentos publicadas no Boletim Oficial. Vejamos o caso do angolano Cute. Ele aparece na coluna de nomes dos falecidos da seguinte forma: "Cute, soldado adido". Caso semelhante é o do português Joaquim, cujo nome aparece da seguinte forma: "Joaquim, soldado 50". Interessantes também são os casos de alguns guineenses, cujos nomes são assim registrados: "Retranca (gentio manjaco)", "Calenga (gentio balanta)" e "Nhlalem, gentio manjaco". Todos estes são casos de pessoas cujos nomes são compostos por um só termo. As locuções que lhes são apostas representam um comentário externo feito pela autoridade médica visando uma identificação mais precisa do indivíduo falecido, não fazendo parte do nome. As vírgulas e parênteses atestam isto, funcionando como marcadores que separam o nome do comentário. Contudo, pequenas variações na forma da inscrição dos nomes nas listas sugerem que o regime de controle da identificação não estava plenamente estabelecido na Guiné colonial. É o caso dos registros de "António Domingos soldado 34", de "José Luís soldado 132" e de "Manuel Joaquim Soldado". Nesses casos já não há mais marcadores visuais a separar o nome do comentário. E como no meio militar os indivíduos também são identificados pela patente e pelo número, parece que o instável regime de nomeação colonial complementava a identificação incompleta feita só com o uso de prenomes com elementos da lógica militar, diminuindo assim a ambigüidade das identidades. De qualquer modo, a retirada sistemática das vírgulas e parênteses, nestes e em outros casos, sugere que se deve compreender tais nomes de modo literal. Esse entendimento ganha suporte quando se considera o terceiro nome do exemplo acima citado. O soldado Manuel Joaquim não aparece numerado, mas o termo "Soldado" é escrito desta vez com a inicial maiúscula. Com esse caso completa-se a passagem, já que o termo "soldado" perdeu o sentido de patente militar e se cristalizou como sobrenome. Só não se sabe se ganhou estabilidade suficiente para ser herdado. Mais uma vez o compromisso que resulta da crioulização foi facilitado pela equivalência entre as vertentes de nomeação européia e africana.

[continuação] Tarde (2001) e Elias (1978), como por ideólogos coloniais apologistas da missão civilizadora dos europeus em África. Sobre estes últimos, ver o interessante trabalho de Saada (2005). Curiosamente, os sociolingüistas têm demonstrado como as formas vernaculares das camadas populares são em muitos casos as fontes de invenção e mudança sociolingüística. Sobre o assunto, consultar o estudo seminal de Labov (1972) sobre o inglês dos negros de Nova Iorque e o de Rickford (1987) sobre o crioulo da Guiana. 
Em ambas é comum que a ocupação se transforme em nome pessoal, com ou sem valor patronímico, com ou sem perda de valor referencial. ${ }^{28}$

Um outro modo de transformar um comentário em sobrenome, que neste caso foi herdado, é exemplificado pelo caso do tecelão Lourenço, solteiro, falecido em Bissau no final de 1897. Seu nome aparece na lista como "Lourenço (Manjaco)". Na ocasião de sua morte, ele tinha uma companheira que estava grávida, cujo filho nasceu algum tempo depois. Em 1900 essa criança morreu e foi registrada na lista dos falecimentos como "Agostinho Manjaco" (sem parênteses). E na coluna da filiação, o que antes era um comentário aposto ao nome do pai se tornou um sobrenome, herdado pela criança falecida. Um último exemplo da instabilidade do regime de registro e identificação nas povoações crioulas da Guiné vem das atas de aforamento de terrenos em Bolama. Em maio de 1890 o Boletim Oficial publicou os pedidos de aforamento de terrenos urbanos em Bolama. Ali estava registrado que João Manjacosinho havia solicitado um terreno, que se confrontava, entre outros, com o de António Gomes Manjaco. As solicitações foram a leilão e o Boletim Oficial publicou em setembro do mesmo ano que o solicitante tivera êxito em obter o aforamento. Desta vez, porém, o proprietário vizinho é registrado como "António Gomes, manjaco" (com vírgula e com a inicial em minúscula). Este é um importante exemplo porque mostra o caminho inverso do trajeto tomado no caso de Lourenço Manjaco. Aqui, o que era um sobrenome construído a partir de um etnônimo deixou de sê-lo para se transformar num comentário. Todos esses casos mostram que a ação simultânea de tendências opostas é um fato corriqueiro nas sociedades crioulas, que se empenham em tempo integral para alcançar um compromisso, sempre frágil, entre as vertentes civilizatórias que as constituíram. O ziguezague, o movimento de vai-e-vem são traços comuns nas sociedades crioulas e no ambiente colonial (Stoler e Cooper 1997: 26).

Formas de nomeação como a de João Manjacosinho trazem à tona a questão do relacionamento entre os nomes usados na esfera familiar e o(s) usado(s) na esfera oficial. Minha experiência de pesquisa de campo na Guiné informa que esse tipo de nome era usado primariamente na esfera familiar e no circuito dos amigos e vizinhos. É comum na Guiné que as pessoas tenham vários nomes, além do nome oficial impresso nos documentos fornecidos pelo Estado. Desde muito pequenas, as pessoas recebem o nomi di kasa pelo qual serão tratadas no decorrer da vida. ${ }^{29}$ Se em princípio é um nome de uso restrito à esfera familiar

28 No mundo mande e, de modo geral, nas sociedades de casta da África Ocidental, o nome de família (jamu) é sempre um índice da ocupação e status da família. Ver Mann (2002).

29 Além do nomi di kasa, as pessoas são conhecidas por nomes de circulação mais restrita. Têm os nomi di torosa (nomes de brincadeira, apelidos), usados exclusivamente por colegas e amigos, os nomi di manjuandadi, usados nas associações de ajuda mútua organizadas com base na faixa etária. Segundo Ampa (1991: 121), a ação de todos eles acaba por tornar inexpressivo o nome oficial. 
e de vizinhança, com o passar do tempo ele ganha livre circulação se tornando público, mas não oficial. Não é incomum que a forma do nome familiar seja a mesma do nome oficial: um ou mais prenomes seguido de um ou mais sobrenomes, que não são necessariamente herdados dos pais. Assim uma pessoa que tem no bilhete de identidade o nome de Francisco Costa pode ter o nomi di kasa Carlos Mendes e ser chamada em família, pelos conhecidos do bairro, pelos colegas de trabalho e escola de Caló ou Lito. Na Guiné colonial não era incomum a publicação de anúncios e éditos do juizado da comarca em que a duplicidade de nomes penetrava e era reconhecida na esfera oficial. Em 1902, um édito judicial afirmava que Victor de Brito Évora era também conhecido por Filipe. Em 1892, o empregado do comércio Victor da Costa Lopes mandou publicar um anúncio no Boletim Oficial no qual prevenia ao público que passaria a assinar o seu nome Victor de Paula Mendes Lopes. Anos mais tarde esse tipo de instabilidade ainda estava em vigor. Em 1940, o cipaio (funcionário subalterno africano) Bentoi Biague foi castigado por desobediência. No telegrama em que a punição era informada à autoridade de Bolama seu nome aparecia seguido pela expressão “(talvez Antonio Bentoi)”. É curioso que mesmo se tratando de um funcionário colonial que recebia regularmente o seu salário e que era parte integrante da maquinaria administrativa, seu nome era fluido e objeto de um "talvez".

Mas é ainda mais comum que a pessoa tenha um nome familiar oriundo da tradição crioula. São termos crioulos, inspirados nas práticas africanas de nomear segundo as circunstâncias do nascimento, os traços físicos e de caráter, as esperanças nele depositadas ou as crenças de natureza mística. São comuns nomes como os quatro que aparecem nas listas de falecimentos e outros como Media (meio-dia), Negadu e Njetadu (negado e enjeitado), El-son ou Ami-son (só ele ou só eu) Abó-ki-bim (tu que chegas), Mortu (morto), Hospri, N’dingui ou Indengue (hóspede) e tantos outros. Sua circulação é de tal modo geral que eles acabam por ter mais reconhecimento que o nome de batismo ou registro. Não é por outra razão que em documentos oficiais como éditos de aforamento, testamentos, atas do concelho de governo e dos tribunais e petições diversas aparecia aposto aos nomes, entre parênteses ou separados por vírgulas, a expressão "vulgo", seguida do nomi di kasa. Em outras ocasiões o nomi di kasa ganha feições de nome oficial quando, por exemplo, o chefe do julgado municipal de Bolama enviou ao diretor da colônia penal da ilha das Galinhas o condenado chamado "Morto", juntamente com um despacho oficial em que constava seu nome, idade, estado civil, local de residência, etnia e a pena a que fora condenado.

Apesar do expressivo número de nomes com um só termo, são 402 os nomes que têm a forma da cadeia sintagmática européia, formada por prenome e sobrenome. Portanto, é preciso olhar para o modo como são atribuídos e para sua forma. A maioria deles é oriunda dos paradigmas portugueses 
dos prenomes e sobrenomes. Os mais comuns entre os últimos eram Silva, Gomes e Correia. Embora sejam poucos os nomes que misturam elementos dos paradigmas africano e cristão, vale a pena ressaltar o trabalho diferenciado da crioulização no encadeamento dos termos pertencentes a tradições diferentes. A pequenez da amostra não permite produzir generalizações sólidas sobre o locus de atuação das mudanças. Porém, é útil para a formulação de hipóteses como as que se seguem. Entre os angolanos, o paradigma dos prenomes era o mais sensível à influência da tradição européia (nomes como José Catume). $\mathrm{O}$ inverso se deu entre os africanos oriundos da África não portuguesa, entre os quais o primeiro a mudar foi o paradigma dos sobrenomes (nomes como Samba Gay). Entre os guineenses, curiosamente, a transformação operou mais fortemente na forma do encadeamento, não se manifestando nas séries dos prenomes e sobrenomes. O quadro 8 mostra os encadeamentos segundo o local de nascimento das pessoas.

\section{Quadro 8}

Combinação das tradições na formação dos nomes

Tipo de encadeamento

Prenome cristão-sobrenome africano

Prenome africano-sobrenome cristão

Prenome africano-sobrenome africano
Angolanos

9

1

1
Guineenses África não portuguesa I

O

2
O

2

0

Do conjunto de 194 pessoas com filiação conhecida, 27 foram registradas com filiação materna, sendo 22 nascidas na Guiné, quatro em Cabo Verde e uma em Angola. Nem todas elas e nem todas as mães tinham nome formado pelo encadeamento de prenome e sobrenome. Quando se olha apenas para esse último grupo, nota-se que, entre os guineenses, oito herdaram o sobrenome da mãe e duas tinham sobrenomes diferentes. Entre os cabo-verdianos, uma herdou o sobrenome da mãe e duas tinham sobrenomes diferentes. E o único angolano com filiação materna tinha sobrenome diferente do registrado para a mãe.

Como é de se esperar, a filiação materna era mais comum entre os guineenses e cabo-verdianos, que ainda hoje vivem em unidades domésticas fortemente centradas na figura da mãe ou avó. O importante papel econômico exercido pelas mulheres nas povoações crioulas e os arranjos conjugais pelos quais os homens circulam por várias unidades domésticas no decorrer da vida adulta operam no sentido de dar maior peso a elas no interior das famílias. A centralidade da mulher na vida das povoações crioulas da Guiné do século XIX é facilmente detectável quando se nota, por exemplo, que cerca de metade 
das licenças de aforamento de terrenos em Bolama era concedida a elas. Esses terrenos se localizavam na parte urbanizada da cidade, o que significa que a eles tinham acesso os grupos mais afluentes da população. E se nesse estrato a mulher se revelava independente e autônoma, o que dizer das que eram recém-chegadas à periferia do mundo crioulo? No entanto, dentre os 27 casos de filiação materna, 18 não herdavam o sobrenome materno. Tenho poucas informações complementares que possam iluminar esses casos, mas suspeito que essas mães davam aos filhos os sobrenomes dos homens que eram tidos como seus pais, embora disto não resultasse o reconhecimento legal de laços de paternidade. Entre as mães oriundas dos estratos mais baixos da população, era comum atribuir aos filhos os sobrenomes das famílias com as quais elas tinham laços de dependência (as gãs crioulas).

Quando se focaliza os casos de filiação paterna, observa-se que a maioria dos filhos herdava pelo menos um sobrenome do pai. Porém, não são poucos os casos em que filhos tinham sobrenomes completamente diferentes do pai, sendo que 11 por cento dos indivíduos com filiação paterna não herdavam o seu sobrenome. Em geral, esses eram casos em que os filhos nasciam de uma relação de conjugalidade de algum modo reconhecida (e por isso o registro anota a filiação paterna), mas não em sua plenitude. Os filhos recebiam assim os sobrenomes das mães ou das famílias com as quais elas estavam ligadas como aderentes e dependentes: criadas, serviçais, intermediárias no comércio ou mesmo antigas escravas domésticas das grandes casas patrimoniais que ainda tinham influência e prestígio no meio crioulo.

O último traço na formação da cadeia sintagmática dos nomes que quero destacar está associado ao uso de marcadores tecnonímicos como "Neto" e "Júnior". Pouco comum em Portugal, mas freqüente na variante brasileira da tradição lusófona, eles só aparecem três vezes nas listas de falecimentos. O primeiro era Matheus Martins Ferreira Júnior, negociante nascido na ilha de São Vicente (Cabo Verde) e falecido na Guiné com 45 anos. Seu pai, como era de se esperar, chamava-se Matheus Martins Ferreira. O segundo se chamava José Carlos Rebello Cabral Júnior. As informações complementares que pude recolher sugerem que a família Rebello Cabral era oriunda da ilha Brava em Cabo Verde. Na Guiné, eram membros da elite crioula, ocupando cargos de prestígio na administração colonial, como facultativo e escrivão da Fazenda. O exame minucioso desse caso revela mais uma vez a instabilidade do regime de nomeação na colônia. Numa subscrição pública destinada à compra de armamentos para a marinha portuguesa em 1890, José Carlos Rebello Cabral Júnior é mencionado juntamente com seu pai, o escrivão da Fazenda José Carlos Rebello Cabral. Contudo, sete anos mais tarde, na publicação da lista de pessoas que arremataram terrenos em Bolama, o nome do pai tomava uma forma ligeiramente diferente: "José Carlos Rebello Cabral Sênior". Tudo isto indica que as instituições do Estado não tinham muito controle sobre o 
registro de nomes e que as partículas tecnonímicas ainda não tinham sido plenamente incorporadas ao nome, funcionando mais como um marcador ou um comentário visando dar mais precisão na identificação. $\mathrm{O}$ uso da partícula "Neto" segue na mesma direção. Seu portador se chamava José R. Naval Neto, falecido com poucos dias de idade em 1899. Era filho de António Diniz Naval, degredado angolano, falecido um ano mais tarde, com 29 anos. Na entrada relativa ao seu falecimento o leitor é surpreendido ao reparar que seu pai se chamava José Barreto, tendo em comum com o neto apenas o prenome José. Não tenho informações complementares que desvendem a lógica por trás do uso dessa partícula. Pode bem ser que ela vise marcar a diferença entre o neto e o avô chamados José, mas pode ser que sirva para marcar outras diferenças.

Para terminar, trago à baila um outro uso da partícula "Júnior" que coletei no livro de testamentos de Bissau, que sugere um sentido diferente para o uso dessas formas de tecnonímia. ${ }^{30} \mathrm{O}$ comerciante Francisco José d'Araújo, nascido na ilha do Fogo (Cabo Verde), faleceu em Bissau em 1885. Em seu testamento, ele deixou a maior parte de seus bens para a irmã, Bernarda Cândida d'Araújo, e os sobrinhos Palmira Cândida d'Araújo e Francisco José d'Araújo Júnior, que em 1910 veio a ser o primeiro presidente de uma associação nativista-nacionalista chamada Liga Guineense. Além de ser uma evidência adicional de que as mães passam prenomes para as filhas, esse testamento sugere que o uso da partícula "Júnior" tinha menos a ver com a relação de filiação e mais com a diferença de gerações no interior de um mesmo grupo. Num ambiente sociocultural organizado em torno de casas patrimoniais com natureza de grupos corporados (as gãs crioulas) em que as mulheres tinham larga autonomia, em estreito contato com as sociedades africanas da costa, quase todas caracterizadas pela descendência matrilinear e pela atuação do princípio da senioridade na organização da cultura política, nada mais gramatical do que herdar o nome do tio materno e usar a partícula tecnonímica "Júnior" para individuar a pessoa que herda.

\section{CONCLUSÕES}

Continuo com o exame do testamento do comerciante Francisco José d'Araújo. A parte da feitoria que tinha em Geba e os créditos que tinha com os mandingas da região foram deixados respectivamente para Joaquina d'Araújo, filha de sua criada Izabel d'Oliveira e para a própria criada. Além disso, deixou uma quantia em dinheiro para duas outras criadas, chamadas Josepha d'Oliveira e Anna d'Araújo. Esse caso sugere que a transmissão do sobrenome passava pelo pertencimento à gã chefiada pelo negociante, embora esta não fosse uma regra 
obrigatória. Uma criada assim como a filha de outra herdaram o sobrenome do comerciante. Infelizmente não disponho de dados complementares que confirmem a continuidade da herança desse sobrenome.

O que esta e outras evidências apresentadas no decorrer desse trabalho sugerem é que a ação da crioulização na Guiné colonial gerou práticas de nomeação instáveis, que muitas vezes tomavam a direção oposta daquela tomada pelo regime dos nomes em Portugal. Juntamente com a adoção de facetas do modelo europeu, a análise das listas mostra o uso transformado de traços oriundos das práticas africanas de nomeação e ainda a introdução de elementos verdadeiramente próprios dessa entidade terceira que é a sociedade crioula, como a incorporação das formas de nomeação originalmente familiares ou regionais (os nomi di kasa) na esfera oficial, a transformação gradativa de etnônimos em patronímicos e vice-versa, o uso criativo dos marcadores tecnonímicos, o costume de passar para as filhas o nome completo das mães e a herança do sobrenome pelo pertencimento a grupos corporados, como as casas patrimoniais, e não pela filiação.

Tendo uma natureza processual, o compromisso alcançado pela crioulização é sempre frágil e instável. Prevaleciam nas povoações crioulas várias práticas de atribuição de nomes em competição. Porém, diferentemente da perspectiva dos ideólogos coloniais que tinham uma crença inabalável na "missão civilizadora" portuguesa e ainda hoje implicitamente defendida por todos os que equiparam os processos de urbanização em África a uma difusa idéia de ocidentalização, o trabalho da crioulização sempre teve a forma de ziguezague, num constante movimento de vai-e-vem. O exame das listas tanto mostra casos de filhos com nomes que se adequavam à risca à cadeia sintagmática do modelo europeu, cujos pais tinham nomes orientados por outros padrões de nomeação (formado só pelo prenome, africano ou cristão), como mostra também casos de pessoas que só tinham um prenome (cristão, crioulo ou africano), que eram filhas de pais nomeados segundo o modelo europeu.

Além disto, espero ter mostrado que a instabilidade também marcava as práticas de nomeação portuguesas, que não estavam consolidadas como tacitamente acreditamos. Na realidade, o que chamei no decorrer desse trabalho de modelo europeu é sobretudo construção post facto cujo valor é de natureza heurística, para fins comparativos.

Instabilidade, tensão, a atuação simultânea de tendências opostas e inventividade marcavam e continuam marcando o trabalho da crioulização na Guiné. As práticas históricas de nomeação nas povoações urbanas da Guiné e a própria sociedade são o produto de uma mistura das tradições, práticas e valores europeus e africanos. A literatura antropológica tem usado contemporaneamente um variado jargão para nomear e analisar essas situações. Hibridez, diáspora, mestiçagem, sincretismo, transculturação, globalização são alguns dos termos que nos últimos 20 anos ganharam uso corrente na disciplina para 
lidar com esse tipo de situação e com a conseqüente crise por que passam as nossas unidades básicas de análise: cultura e sociedade. Nesse trabalho optei por um outro termo, crioulização, porque acredito que ele tem maior potencial analítico. Creio que analisar a variação nas práticas de nomeação de modo análogo ao dos sociolingüistas, que focalizam as relações entre os vários lects dos crioulos para compreender a mudança lingüística, me leva muito além do simples reconhecimento das misturas, interpenetrações, fluxos e indefinição das fronteiras sociais e culturais. Permite compreender os detalhes do processo de transformação, reconhecer quando e em que parte do sistema em questão uma determinada tendência ou fluxo se manifesta ou prevalece, e ainda circunscrever as fontes e a natureza da invenção social.

\section{BIBLIOGRAFIA}

AMPA, J., 1991, “Nomi di kasa”, Papia (Revista de Crioulos de Base Ibérica), 1 (2): pp. 119 -121 .

AMSElle, J.-L., 1990, Logiques Métisses: Anthropologie de l'Identité em Afrique et Ailleus. Paris, Éditions Payot.

ASTRIÉ, M., 1885, "La Guinée portugaise", Boletim da Sociedade de Geografia de Lisboa (BSGL), 5 (9), pp. 564-568.

BA, A.H., 1981, "La notion de personne en Afrique Noire", em G. Dieterlen (dir.), La Notion de Personne en Afrique Noire. Paris, Editions du CNRS.

BARroS, M.M., 1882, "Guiné Portugueza: ou breve notícia sobre alguns dos seus usos, costumes, línguas e origens de seus povos", BSGL, 3 (12), pp. 707-724.

BASTIDE, R., 1981, “Le principe d'individuation (contribuition à une philosophie africaine)”, em G. Dieterlen (dir.), La Notion de Personne en Afrique Noire. Paris, Editions du CNRS.

BOWMAN, J., 1997, Ominous Transition: Commerce and Colonial Expansion in the Senegambia and Guinea, 1857-1919. Aldershot, Avebury.

—, 1987, "Legitimate commerce and peanut production in Portuguese Guinea, 18401880", Journal of African History, 28 (1), pp. 87-106.

BragA, T., 1995, O Povo Português nos Seus Costumes, Crenças e Tradições (2 vols.). Lisboa, Publicações Dom Quixote.

BRITO, E., 1955, “Onomástica fula e graus de parentesco", Boletim Cultural da Guiné Portuguesa (BCGP), 40, pp. 599-615.

BROSSElARD, H., 1889, "Voyage dans la Sénégambie et la Guinée Portugaise”, Le Tour du Monde (Nouveau Journal des Voyages), 57, pp. 97-144. 
CAPLAN, J., 2001, "This or that particular person: protocols of identification in nineteenth-century Europe”, em J. Caplan e J. Torpey (eds.), Documenting Individual Identity. Princeton, Princeton University Press.

CARREIRA, A., 1967, "Manjacos-brames e balantas (aspectos demográficos)”, BCGP, 85-86, pp. 41-92.

—, 1962, População Autóctone segundo os Recenseamentos para Fins Fiscais (separata dos números 57-58 do vol. XV, 61-62 do vol. XVI, 65, 66 e 67 do vol. XVII do Boletim Cultural da Guiné Portuguesa). Bissau, Centro de Estudos da Guiné Portuguesa.

—, 1961, "Recenseamento da população. Índices de poligamia”, BCGP, 64, pp. 769-782.

—_, 1959, “População civilizada da Guiné em 1950”, BCGP, 56, pp. 547-568.

_-, 1951, "A poligamia entre os grupos étnicos da Guiné Portuguesa”, BCGP, 24, pp. 927-945.

CARreIRA, A., e F. R. Quintino, 1966, Antoponímia da Guiné Portuguesa (2. ${ }^{\circ}$ volume). Lisboa, Memórias da Junta de Investigações do Ultramar.

—_, 1964, Antoponímia da Guiné Portuguesa (1. ${ }^{\circ}$ volume). Lisboa, Memórias da Junta de Investigações do Ultramar.

COElHO, A., 1993, Obra Etnográfica (volume 1): Festas, Costumes e Outros Materiais Para Uma Etnologia de Portugal. Lisboa, Publicações Dom Quixote.

COUTO, H.H., 1996, Introdução ao Estudo das Linguas Crioulas e Pidgins. Brasília, Editora da Universidade de Brasília.

—_, 1987/1988, “Os apelidos do Cláudio”, Humanidades, 11, pp. 65-70.

DIETERLEN, G., 1981, "L'image du corps set les composants de la personne chez les dogon”, em G. Dieterlen (dir.), La Notion de Personne en Afrique Noire. Paris, Editions du CNRS.

DUQUeTE, D. G., 1983, Dynamique de l’Art Bidjogo. Lisboa, Instituto de Investigação Científica Tropical.

EINARSDÓTTIR, J., 2000, Tired of Weeping: Child Death and Mourning Among Papel Mothers in Guinea-Bissau. Södertälje, Almqvist \& Wiksell International.

ELIAS, N., 1978, The Civilizing Process: The History of Manners. Nova Iorque, Pantheon Books.

FORTES, M., 1981, "On the concept of the person among the Tallensi”, em G. Dieterlen (dir.), La Notion de Personne en Afrique Noire. Paris, Editions du CNRS.

HAVIK, P., 2004, Silences and Soundbytes: The Gendered Dynamics of Trade and Brokerage in the Pre-Colonial Guinea Bissau Region. Münster, LIT Verlag.

HENRI, C., 1994, Les Îles où Dansent les Enfants Défunts : Âge, Sexe et Pouvoir Chez les Bijogo de Guinée-Bissau. Paris, Éditions CNRS.

HUNT, N.R., 1991, "Noise over camouflaged polygamy, colonial morality taxation, and a woman-naming crisis in Belgian Africa", The Journal of African History, 32 (3), pp. 471 $-494$.

KOPYTOFF, I., 1987, "The internal African frontier: The making of African political culture”, em I. Kopytoff (ed.), The African Frontier. Bloomington, Indiana University Press.

—, 1971, "Ancestors as elders in Africa, Africa, 41 (2), pp. 129-142.

LABOV, W., 1972, Language in the Inner City: Studies in the black English Vernacular. Filadélfia, University of Pennsylvania Press.

LÉVI-STRAUSS, C., 1976, O Pensamento Selvagem. São Paulo, Companhia Editora Nacional. LiTTle, Kenneth L., 1967, The Mende of Sierra Leone. A West Africa People in Transition. Londres, Routledge \& Kegan Paul. 
LOPES DE LIMA, J. J., 1844, Ensaio sobre a Statística das Possessões Portuguezas, livro I (partes 1 e 2). Lisboa, Imprensa Nacional.

MACCORMACK, Carol P., 1979, "Sande: the public face of a secret society", em B. Jules-Rosette (ed.), The New Religions of Africa. Borwood, Ablex Publishing Corporation.

MANN, G., 2002, "What's in an alias? Family names, individual histories, and historical method in the Western Sudan", History in Africa, 29, pp. 309-320.

MARTI, P., 1981, "Le nom et la personne chez les sabé (Dahomey), em G. Dieterlen (dir.), La Notion de Personne en Afrique Noire. Paris, Editions du CNRS.

MENEZES, V.H., 1928, “Questionário de inquérito sobre as raças da Guiné e seus caracteres étnicos formulado pelo governo da colónia em portaria provincial $n^{\circ} 70$, de 12 de abril de 1927, acerca da Circunscrição Civil de Costa de Baixo", Apenso ao Boletim Oficial da Província da Guiné Portuguesa (BOGP), n. ${ }^{\circ} 3$.

MIGEOD, F.W.H., 1917, "Personal Names among some West African Tribes", Journal of the Royal African Society, 65, pp. 38-45.

NOIRIEL, G., 2001, "The identification of the citizen: the birth of republican civil status in France", em J. Caplan e J. Torpey (eds.), Documenting Individual Identity. Princeton, Princeton University Press.

PÉLISSIER, R., 1989, História da Guiné: Portugueses e Africanos na Senegâmbia (1841-1936), 2 volumes. Lisboa, Editorial Estampa.

PIMENTEL, A. G., 1927, “Questionário de inquérito sobre as raças da Guiné e seus caracteres étnicos formulado pelo governo da colónia em portaria provincial n ${ }^{\circ} 70$, de 12 de abril de 1927, acerca da Circunscrição Civil de Mansoa", Apenso ao BOGP, n. ${ }^{\circ} 50$.

PINA CABRAL, João de, 2003, O Homem na Família: Cinco Ensaios de Antropologia. Lisboa, Imprensa de Ciências Sociais.

Província da Guiné, 1948, Anuário da Guiné Portuguesa 1948. Bissau.

—, 1946, Anuário da Guiné Portuguesa 1946. Bissau.

QUINTINO, F. R., 1969, “Os povos da Guiné”, BCGP, 96, pp. 861-915.

RICKFORD, J.R., 1987, Dimensions of a Creole Continuum: History, Texts, and Linguistic Analysis of Guyanese Creole. Stanford, Stanford University Press.

RIESMAN, P., 1998, Freedom in Fulani Social Life. Chicago, The University of Chicago Press.

SAADA, E., 2005, “Entre 'assimilation' et 'décivilisation': L'imitation et le projet colonial républicain”, Terrain, 44, pp. 19-38.

SANTOS limA, A. J., 1947, Organização Econômica e Social dos Bijagós. Bissau, Centro de Estudos da Guiné Portuguesa.

SCOTT, J. C., et al., 2002, "The production of legal identities proper to states: the case of the permanent family surname”, Comparative Study in Society and History, 44 (1), pp. 4-44.

STOLER, A.L., e F. Cooper, 1997, "Between metropole and colony: Rethinking a research agenda”, em F. Cooper e A. L. Stoler (eds.), Tensions of Empire: Colonial Cultures in a Burgeois World. Berkeley, University of California Press.

TARDE, G., 2001, Les Lois de l'Imitation. Paris, Éditions du Seuil.

TEIXEIRA DA MOTA, A., 1950, "A agricultura de brames e balantas vista através da fotografia aérea”, BCGP, 18, pp. 131-171.

THOMAS, L.-V., 1959, Les Diola: Essai d'Analyse Fonctionelle sur une Population de Basse-Casamance. Dakar, IFAN.

TRAJANO FILHO, W., 2005a, "A crioulização na Guiné-Bissau: um caso singular", Estudos Afro-Asiáticos, 27, pp. 57-102. 
TRAJANO FILHO, W., 2005b, "A construção da nação e o fim dos projetos crioulos", em T. Cruz e Silva, M. G. Mendes de Araújo e C. Cardoso (orgs.), "Lusofonia em África”: História, Democracia e Integração Africana. Dakar, Codesria.

—, 1998, Polymorphic Creoledom: The "Creole Society" of Guinea-Bissau. Dissertação de doutoramento, University of Pennsylvania.

VASCONCElOS, E.J., 1917, Guiné Portuguesa: Estudo Elementar de Geografia Física, Económica e Política. Lisboa, Tipografia da Cooperativa Militar.

ZONABEND, F., 1977, "Pourquoi nommer? Les noms de personnes dans un village français: Minot-em-Chatillonnais”, em C. Lévi-Strauss (dir.), L'Identité: Séminaire Interdisciplinaire. Paris, Grasset.

The workings of Creolization: naming practices in colonial Guinea-Bissau - Wilson Trajano Filho - Departamento de Antropologia da Universidade de Brasília e investigador associado do Instituto Max-Planck de Antropologia Social (Haale/Saale, Alemanha) • trajano@unb.br

This paper analyses the naming practices in the creolized villages of Guinea-Bissau during the colonial period. Based on a corpus of 496 names presented in a series of lists of deceased persons published by the Health Service between 1892 and 1900, this article describes the process of creolization in colonial society from the perspective of the naming practices. Comparing the naming patterns prevailing in Portugal and in the indigenous societies of Guinea, this paper shows how Creole naming practices were unstable, creative and multidirectional.

KEYWORDS: creolization, naming practices, Guinea-Bissau. 